\title{
Analisis Faktor-Faktor Yang Mempengaruhi Minat Pemanfaatan Sistem Informasi Dan Ekspektasi Kinerja Terhadap Penggunaan Sistem Informasi (Studi Kasus: Sekolah Tinggi Xyz) \\ Analysis of Factors That Affecting The Interest of Information System Utilization and Performance Expectations on Information System Use (Case Study: Xyz Academy)
}

\author{
Anggoro Aryo ${ }^{1}$, Mulyati ${ }^{2}$ \\ ${ }^{1,2}$ Program Studi Sistem Informasi, STMIK GI MDP \\ E-mail: ${ }^{1}$ anggoro_aryop@mdp.ac.id, ${ }^{2}$ muliati@mdp.ac.id
}

\begin{abstract}
Abstrak
Penerapan sistem informasi secara luas telah digunakan pada berbagai bidang termasuk juga pada bidang pendidikan. Penelitian ini bertujuan untuk menguji faktor-faktor yang mempengaruhi minat pemanfaatan sistem informasi, ekspektasi kinerja terhadap penggunaan sistem informasi di Sekolah Tinggi XYZ. Metode yang digunakan penulis dalam pengumpulan data ini adalah angket (questionnaire), pengolahan dan analisa data dilakukan dengan menggunakan metode Structural Equation Modeling (SEM) dengan bantuan software aplikasi SmartPLS Versi 3.2.8. Hasil penelitian ini menunjukkan bahwa hasil uji hipotesis terhadap variabel minat pemanfaatan sistem informasi (H1) tidak memiliki pengaruh secara positif ke variabel penggunaan sistem informasi sehingga hipotesis H1 ditolak, sedangkan uji hipotesis varibael ekspektasi kinerja $(\mathrm{H} 2)$ berpengaruh positif terhadap penggunaan sistem informasi sehingga hipotesis $\mathrm{H} 2$ diterima. Hasil uji ini mengidentifikasi penggunaan sistem informasi dan ekspektasi kinerja bahwa responden merasa bahwa adanya sistem informasi dapat membantu meningkatkan kinerja dalam meningkatkan kualitas output pekerjaan dan lebih meningkatkan kualitas proses belajar mengajar di Sekolah Tinggi XYZ.
\end{abstract}

Kata kunci: ekspektasi kinerja, minat pemanfaatan sistem informasi, penggunaan sistem informasi, PLS

\begin{abstract}
The application of information systems has been widely used in various fields including education. This study aims to examine the factors that affect the intention to use information systems,performance expectations of the use of information systems in XYZ Academy. The method used by the author in collecting this data is a questionnaire, data processing and analysis is performed using the Structural Equation Modeling (SEM) method with the help of SmartPLS Version 3.2.8 application software. The results of this study indicate that the results of hypothesis testing on the variable intention to use information systems (HI) do not have a positive influence on the information system use variables so $\mathrm{HI}$ is rejected, whereas the hypothesis test of performance expectations (H2) has a positive effect on the use of information systems in this way $\mathrm{H} 2$ received. The results of this test identify the use of information systems and performance expectations that respondents feel that the existence of an information system can help improve performance in improving the quality of work output and further improve the quality of teaching and learning in XYZ Academy.
\end{abstract}

Keywords: performance expectations, the intention to use information systems, the use of information systems, PLS 


\section{PENDAHULUAN}

\subsection{Latar Belakang}

Perkembangan sistem informasi yang semakin cepat berdampak pada semua sektor kegiatan bisnis. Secara umum, sistem informasi diartikan sebagai suatu sistem dalam organisasi yang digunakan untuk mengolah data menjadi informasi yang bermanfaat dalam mencapai tujuannya. Sistem informasi terdiri dari elemen-elemen yang saling berhubungan satu sama lain sehingga membentuk satu kesatuan untuk mengintegrasi data, memproses dan menyimpan, serta mendistribusikan informasi. Menurut Hall [9], sistem informasi adalah serangkaian prosedur formal ketika suatu data dikumpulkan, diproses menjadi informasi yang berguna, dan kemudian didistribusikan kepada para pemakainya.

\subsection{Tinjauan Pustaka}

\subsubsection{Sistem Informasi (SI)}

Bodnar dan Hopwood [1] mendefinisikan sistem dalam lingkup SI sebagai sumber daya yang bekerja sama untuk memenuhi tujuan tertentu. Hall [2] mendefinisikan SI sebagai suatu rangkaian prosedur formal dimana data dikumpulkan, diproses menjadi informasi, dan distribusikan kepada para pemakai. Menurut Lucas [3], sistem informasi adalah suatu kegiatan dari prosedur-prosedur yang diorganisasikan, bilamana dieksekusikan akan menyediakan informasi yang dapat mendukung pengambilan keputusan dan pengendalian organisasi. Leitch dan Davis (1993) dalam Afrizon [4] sistem informasi merupakan suatu sistem di dalam organisasi yang mempertemukan kebutuhan pengelolaan transaksi harian, mendukung operasi, bersifat manajerial dan kegiatan strategi dari suatu organisasi dan menyediakan pihak luar tertentu dengan laporan-laporan yang diperlukan.

Setiap organisasi harus menyesuaikan SI dengan kebutuhan pemakai. Oleh karena itu tujuan penggunaan SI yang spesifik dapat berbeda-beda dari satu perusahaan dengan perusahaan lain, namun demikian, terdapat tiga tujuan utama yang umum bagi semua sistem [2] yaitu:

1. Untuk mendukung fungsi kepengurusan (stewardship) manajemen.

2. Untuk mendukung pengambilan keputusan manajemen

3. Mendukung kegiatan perusahaan hari demi hari.

Menurut Hall [2], informasi yang dihasilkan oleh SI dapat digunakan dalam pengambilan keputusan apabila informasi tersebut berkualitas artinya informasi tersebut harus memenuhi empat hal yaitu:

1. Relevan (relevance)

Informasi harus memberikan manfaat bagi pemakainya. Relevansi informasi untuk tiap-tiap individu satu dengan yang lainnya berbeda. Misalnya informasi mengenai sebab-musabab kerusakan mesin produksi kepada akuntan perusahaan adalah kurang relevan dan akan lebih relevan bila ditujukan kepada ahli teknik perusahaan

2. Akurasi (accuracy)

Informasi harus bebas dari kesalahan-kesalahan dan tidak bias atau menyesatkan, dan harus jelas mencerminkan maksudnya. Ketidak akuratan dapat terjadi karena sumber informasi (data) mengalami gangguan atau kesengajaan sehingga merusak atau merubah data-data asli tersebut.

3. Tepat waktu (timeliness)

Informasi yang dihasilkan atau dibutuhkan tidak boleh terlambat (usang). Informasi yang usang tidak mempunyai nilai yang baik, sehingga kalau digunakan sebagai dasar dalam pengambilan keputusan akan berakibat fatal atau kesalahan dalam keputusan dan tindakan. Kondisi demikian menyebabkan mahalnya nilai suatu informasi, sehingga kecepatan untuk mendapatkan, mengolah dan mengirimkannya memerlukan teknologi-teknologi terbaru. 


\section{Lengkap (complete)}

Bagian informasi yang esensial bagi pemakai tidak boleh ada yang hilang atau kurang. Misalnya: sebuah laporan harus menyajikan semua perhitungan dan menyajikannya dengan jelas sehingga tidak menimbulkan laporan yang ambigu.

Dari uraian diatas dapat disimpulkan bahwa SI merupakan sumber daya yang dimiliki organisasi dan sangat bermanfaat dan sebagai sumber pengetahuan bagi penggunaanya. Jika informasi disajikan berkualitas dapat mengurangai resiko ketidak pastian sehingga pengambilan keputusan lebih cepat serta dapat meningkatkan kinerja perusahaan.

Sistem Informasi (SI)

\subsubsection{Minat Pemanfaatan Sistem Informasi}

Triandis [5] mengemukakan bahwa perilaku seseorang merupakan ekspresi dari keinginan atau minat seseorang (intention), dimana keinginan tersebut dipengaruhi oleh faktorfaktor sosial, perasaan (affect) dan konsekuensi- konsekuensi yang dirasakan (perceived consequences). Minat pemanfaatan teknologi informasi (behavioral intention) didefinisikan sebagai tingkat keinginan atau niat pemakai menggunakan sistem secara terus menerus dengan asumsi bahwa mereka mempunyai akses terhadap informasi. Seorang akan berminat menggunakan suatu teknologi informasi yang baru apabila si pengguna tersebut meyakini dengan menggunakan teknologi informasi tersebut akan meningkatkan kinerjanya, menggunakan teknologi informasi dapat dilakukan dengan mudah, dan si pengguna tersebut mendapatkan pengaruh lingkungan sekitarnya dalam menggunakan teknologi informasi tersebut.

Davis et. al. [6] mengemukan bahwa adanya manfaat yang dirasakan oleh pemakai SI akan meningkatkan minat mereka untuk menggunakan SI. Sedangkan Thompson et. al. [7] menyatakan bahwa keyakinan seseorang akan kegunaan SI akan meningkatkan minat mereka dan pada akhirnya individu tersebut akan menggunakan SI dalam pekerjaaannya. Venkatesh et. al. [8] menyatakan bahwa terhadap adanya hubungan langsung dan signifikan anatara minat pemanfaatan SI terhadap penggunaan SI.

\subsubsection{Penggunaan Sistem Informasi}

Perilaku penggunaan teknologi informasi (use behavior) didefinisikan sebagai intensitas dan atau frekuensi pemakai dalam menggunakan teknologi informasi. Perilaku penggunaan teknologi informasi sangat bergantung pada evaluasi pengguna dari sistem tersebut. Suatu teknologi informasi akan digunakan apabila pemakai teknologi informasi tersebut berminat dalam menggunakan teknologi informasi tersebut karena keyakinan bahwa menggunkan teknologi informasi tersebut dapat meningkatkan kinerjanya, menggunakan teknologi informasi dapat dilakukan dengan mudah, dan pengaruh lingkungan sekitarnya dalam menggunakan teknologi informasi tersebut. Selain itu, perilaku penggunaan teknologi informasi juga dipengaruhi oleh kondisi yang memfasilitasi pemakai dalam menggunakan teknologi informasi tersebut karena apabila teknologi informasi tersebut tidak didukung oleh peralatan-peralatan, dan fasilitas-fasilitas yang diperlukan maka penggunaan teknologi informasi tersebut tidak dapat terlaksana. Menurut Handayani [9], Penggunaan SI sebagai perilaku seorang individu untuk menggunakan SI karena adanya manfaat yang akan diperoleh untuk membantu dalam menyelesaikan pekerjaannya. Ketika suatu sistem dipercaya menjadi lebih berguna, lebih penting atau memberikan keuntungan relatif maka akan menimbulkan minat seseorang untuk menggunakan sistem tersebut.

\subsubsection{Ekspektasi Kinerja}

Venkatesh, et al. [8] mendefinisikan Ekspektasi Kinerja (performance expectancy) sebagai tingkat dimana seseorang mempercayai dengan menggunakan sistem tersebut akan membantu orang tersebut untuk memperoleh keuntungan- keuntungan kinerja pada pekerjaan. 
Ekspektasi kinerja (performance expectancy) didefinisikan sebagai tingkat dimana seorang individu meyakini bahwa dengan menggunakan sistem akan membantu dalam meningkatkan kinerjanya. Konsep ini menggambarkan manfaat sistem bagi pemakainya yang berkaitan dengan perceived usefulnees, motivasi ekstrinsik, job fit, keuntungan relatif (relative advantage) [8]. Perceived usefulness mempunyai hubungan yang lebih kuat dan konsisten dengan sistem informasi [6]. Penelitian Venkatesh dan Davis [18] menunjukkan hasil yang mendukung bahwa perceived usefulness merupakan faktor penentu yang signifikan terhadap kemauan individu untuk menggunakan sistem. Thompson et al [7] menemukan adanya hubungan positif yang kuat antara kesesuaian tugas (job fit) dengan penggunaan sistem. Penelitian Diana [10] menunjukkan bahwa kesesuian tugas akan berpengaruh signifikan positif terhadap kinerja karyawan akuntasi. Venkatesh et. al.[8] menyatakan bahwa konstruk ekspektasi kinerja merupakan prediktor yang kuat dari minat pemanfaatan SI dalam setting sukarela maupun wajib. Hal tersebut konsisten dengan penelitian yang dilakukan oleh Compeau dan Higgins [11]; Davis et. al. [6]; Thompson et. al. [7] Venkatesh dan Davis [8].

\subsection{Rumusan Masalah}

Kelangsungan hidup perusahaan sangat ditentukan oleh kemampuannya untuk bersaing di pasar. Kemampuan bersaing memerlukan strategi yang dapat memanfaatkan semua kekuatan dan peluang yang ada, serta menutup kelemahan dan menetralisasi hambatan strategis dalam dinamika bisnis yang dihadapi. Semua itu dapat dilakukan apabila manajemen mampu melakukan pengambilan keputusan yang didasarkan pada informasi yang berkualitas. Informasi yang berkualitas akan terbentuk dari adanya SI yang dirancang dengan baik. Pengunaan SI dalam organisasi telah meningkat secara dramatis. Sejak tahun 1980-an, sekitar 50 persen modal baru digunakan untuk pengembangan SI (Westland dan Clark, 2000) dalam Venkatesh et. al. [8] Sistem informasi diadakan untuk menunjang aktifitas usaha di semua tingkatan organisasi. Penggunaan SI mencakup sampai ke tingkat operasional untuk meningkatkan kualitas produk serta produktivitas operasi. Oleh karena itu SI harus dapat diterima dan digunakan oleh seluruh karyawan dalam organisasi sehingga investasi yang besar untuk pengadaan SI akan diimbangi pula dengan produktivitas yang besar pula. Suatu organisasi perlu memperhatikan adanya faktor-faktor yang dapat mempengaruhi penggunaan SI sehingga tidak akan terjadi "productivity paradox" yaitu investasi yang mahal di bidang SI tetapi menghasilkan return yang rendah. Untuk itu perlu dilakukan pengujian empiris mengenai faktor-faktor yang mempengaruhi minat pemanfaatan SI dan pengaruhnya terhadap penggunaan SI

Adapun permasalahan yang akan diteliti dapat dirumuskan dalam bentuk pertanyaan sebagai berikut: Apakah terdapat pengaruh positif signifikan ekspektasi kinerja dan minat pemanfaatan SI terhadap penggunaan sistem informasi?

\subsection{Tujuan dan Manfaat Penelitian}

\subsubsection{Tujuan}

Sesuai dengan permasalahan yang akan diteliti, maka tujuan penelitian adalah untuk menemukan bukti empiris untuk menguji variabel ekspektasi kinerja dan minat pemanfaatan SI terhadap penggunaan SI.

\subsubsection{Manfaat Penelitian}

Hasil penelitian ini diharapkan dapat memberikan manfaat sebagai berikut:

1. Memberikan kontribusi pada pengembangan teori, terutama yang berkaitan dengan SI yang berhubungan dengan faktor-faktor yang mempengaruhi penggunaan SI.

2. Memberikan kontribusi bagi manajemen organisasi mengenai perilaku individu dalam memanfaatkan SI untuk meningkatkan kinerja individu dan organisasi.

3. Memberikan kontribusi bagi pengembang SI untuk memperhatikan faktor-faktor yang dapat menpengaruhi penggunaan SI sehingga SI yang dikembangkan akan memberikan manfaat bagi organisasi. 


\section{METODE PENELITIAN}

\subsection{Desain Penelitian}

Menurut Sugiyono [12], metode penelitian merupakan cara ilmiah untuk mendapatkan data dengan tujuan dan kegunaan tertentu. Cara ilmiah berarti kegiatan penelitian itu didasarkan pada ciri-ciri keilmuan yaitu rasional, empiris, dan sistematis. Berdasarkan hal tersebut terdapat empat kata kunci yang perlu diperhatikan yaitu cara ilmiah, data, tujuan dan kegunaan. Pada penelitian kali ini, metode penelitian yang digunakan oleh penulis adalah metode penelitian kuantitatif. Pengertian metode penelitian kuantitatif menurut Sugiyono [13] yaitu "metode penelitian yang berlandaskan pada filsafat positivisme, digunakan untuk meneliti pada populasi atau sampel tertentu, teknik, pengambilan sampel pada umumnya dilakukan secara random, pengumpulan data menggunakan instrumen penelitian, analisis data bersifat kuantitatif/statistik dengan tujuan untuk menguji hipotesis yang telah ditetapkan." Dalam melakukan penelitian ini penulis menggunakan pendekatan penelitian dengan metode pendekatan deskriptif dan verifikatif. Metode deskriftif yaitu metode penelitian yang digunakan untuk menggambarkan atau menganalisis suatu hasil penelitian tetapi tanpa bermaksud membuat kesimpulan yang lebih luas [14].

\subsection{Variabel Penelitian dan Definisi Operasional Variabel}

Variabel penelitian adalah segala sesuatu yang berbentuk apa saja yang ditetapkan oleh peneliti untuk dipelajari sehingga diperoleh informasi tentang hal tersebut, kemudian ditarik kesimpulannya [12]. Operasional variabel diperlukan guna menentukan jenis dan indikator dari variabel-variabel yang terkait dalam penelitian ini. Disamping itu, operasionalisasi variabel bertujuan untuk menentukan skala pengukuran dari masing-masing variabel, sehingga pengujian hipotesis dengan menggunakan alat bantu dapat dilakukan dengan tepat.

\subsubsection{Minat Pemanfaatan Sistem Informasi}

Minat pemanfaatan SI didefinisikan sebagai tingkat keinginan atau niat pemakai menggunakan sistem secara terus menerus dengan asumsi bahwa mereka mempunyai akses terhadap informasi. Dalam penelitian ini, minat pemanfaatan SI sebagai variabel dependen akan diukur dengan menggunakan instrumen Davis et al. [6] yang terdiri dari 3 item.

\subsubsection{Ekspektasi Kinerja}

Ekspektasi kinerja didefinisikan sebagai tingkat dimana seorang individu meyakini bahwa menggunakan sistem akan membantu dalam meningkatkan kinerjanya. Variabel ini diukur berdasarkan instrumen Davis et. al. [6], Moore dan Benbasat [15], Thompson et. al. [7] dan Compeau et. al. [11]. Variabel ini diukur dengan menggunakan 6 item yang berkaitan dengan kegunaan persepsian (perceived usefulness), motivasi ekstrinsik (extrinsic motivation), kesesuaian tugas (job-fit), keuntungan relatif (relative advantage) dan ekspektasi hasil (outcome expectation).

\subsubsection{Penggunaan Sistem Informasi}

Penggunaan Sistem Informasi didefinisikan sebagai perilaku seorang individu yang menggunakan SI karena adanya manfaat yang akan diperoleh untuk membantu dalam menyelesaikan pekerjaannya. Pengukuran penggunaan SI akan menggunakan instrumen yang dikembangkan oleh Thompson et. al. [7] yang terdiri dari pengukuran minat penggunaan, frekuensi penggunaan dan jumlah jenis perangkat lunak yang digunakan.

\subsection{Pengembangan Hipotesis}




\subsubsection{Pengaruh Ekspektasi Kinerja terhadap Minat Pemanfaatan Sistem}

Ekspektasi kinerja (performance expectancy) didefinisikan sebagai tingkat dimana seorang individu meyakini bahwa dengan menggunakan sistem akan membantu dalam meningkatkan kinerjanya. Konsep ini menggambarkan manfaat sistem bagi pemakainya yang berkaitan dengan perceived usefulnees, motivasi ekstrinsik, job fit, keuntungan relatif (relative advantage) [8]. Perceived usefulness mempunyai hubungan yang lebih kuat dan konsisten dengan sistem informasi [6]. Venkatesh dan Davis [8] menunjukkan hasil yang mendukung bahwa perceived usefulness merupakan faktor penentu yang signifikan terhadap kemauan individu untuk menggunakan sistem.

Thompson et. al., [7] menemukan adanya hubungan positif yang kuat antara kesesuaian tugas (job fit) dengan penggunaan sistem. Penelitian Diana [9] menunjukkan bahwa kesesuian tugas akan berpengaruh signifikan positif terhadap kinerja karyawan akuntasi. Venkatesh et. al., [18] menyatakan bahwa konstruk ekspektasi kinerja merupakan prediktor yang kuat dari minat pemanfaatan SI dalam setting sukarela maupun wajib. Hal tersebut konsisten dengan penelitian yang dilakukan oleh Compeau dan Higgins [11]; Davis et al [6]; Thompson et al [7]; Venkatesh dan Davis [8].

Berdasarkan uraian teoritis dan beberapa penelitian terdahulu tentang pengaruh ekspektasi kinerja terhadap minat pemanfaatan SI, maka hipotesis 1 (satu) dinyatakan:

H1: Ekspektasi kinerja mempunyai pengaruh positif signifikan terhadap penggunaan sistem informasi

\subsubsection{Pengaruh Minat Pemanfaatan Sistem Informasi terhadap Penggunaan Sistem Informasi}

Triandis [5] mengemukakan bahwa perilaku seseorang merupakan ekspresi dari keinginan atau minat seseorang (intention), dimana keinginan tersebut dipengaruhi oleh faktorfaktor sosial, perasaan (affect) dan konsekuensi-konsekuensi yang dirasakan (perceived consequences). Davis et. al., [6] mengemukakan bahwa adanya manfaat yang dirasakan oleh pemakai SI akan meningkatkan minat mereka untuk menggunakan SI. Sedangkan Thompson et. al., [7] menyatakan bahwa keyakinan seseorang akan kegunaan SI akan meningkatkan minat mereka dan pada akhirnya individu tersebut akan menggunakan SI dalam pekerjaannya atau dengan kata lain adanya imbalan di masa depan juga merupakan suatu faktor yang dapat mempengaruhi minat pemanfaatan SI terhadap penggunaan SI.

Penelitian Venkatesh et. al., [8] menyatakan bahwa terdapat adanya hubungan langsung dan signifikan antara minat pemanfaatan SI terhadap penggunaan SI. Berdasarkan hasil penelitian maka peneliti mengajukan hipotesis dua sebagai berikut:

$\mathrm{H} 2$ : Minat pemanfaatan sistem informasi mempunyai pengaruh positif signifikan terhadap penggunaan sistem informasi

\subsection{Kerangka Konseptual}

Model kerangka konseptual menggambarkan hubungan antar variabel yang diuji dalam penelitiaan. Kerangka konseptual menggambarkan hubungan variabel ekspektasi kinerja dan minat pemanfaatan SI terhadap penggunaan SI. Adapun gambar kerangka konseptual adalah sebagai berikut:

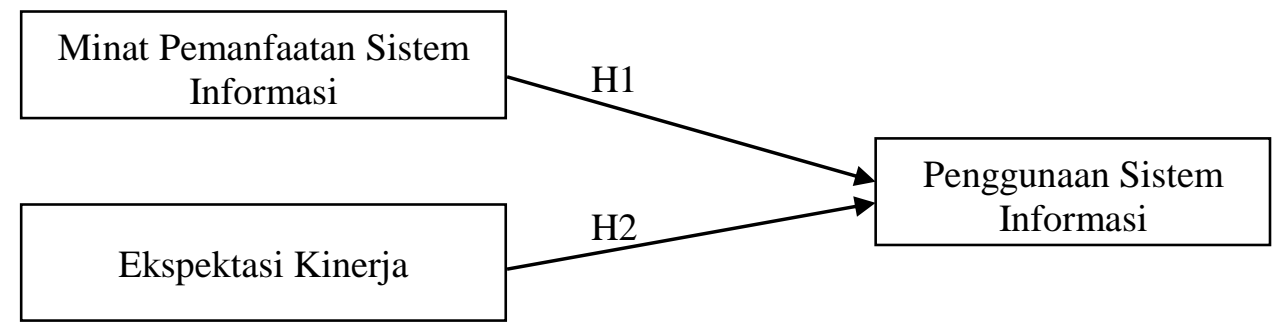

Gambar 1. Kerangka Konseptual 


\subsection{Metode Pengumpulan Data}

Metode yang digunakan penulis dalam pengumpulan data ini adalah Angket (questionnaire). Dalam penelitian ini penulis menggunakan Skala Likert. Skala Likert digunakan untuk mengukur sikap, pendapat, dan presepsi seseorang atau sekelompok orang tentang fenomenan sosial [12]. Dengan Skala Likert, maka variabel yang akan diukur dijabarkan menjadi indikator variabel. Kemudian indikator tersebut dijadikan sebagai titik tolak untuk menyusun item-item instrumen yang berupa pernyataan atau pertanyaan. Skala Likert, yaitu dengan tingkat jawaban terdiri atas 5 tingkatan. Alternatif jawaban tersebut dapat diberi skor dari nilai 1 sampai 5 sebagai berikut:

$$
\begin{aligned}
& 5=\text { Sangat Setuju } \\
& 4=\text { Setuju } \\
& 3=\text { Netral } \\
& 2=\text { Tidak Setuju } \\
& 1=\text { Sangat Tidak Setuju }
\end{aligned}
$$

\subsection{Metode Analisis Data}

Metode yang digunakan untuk menganalisis data adalah metode statistik dengan teknik multivariate SEM (Structural Equation Modeling) menggunakan software aplikasi SmartPLS Versi 3.2.8. Structural equetion modeling (SEM) digunakan untuk menilai hubungan antara konstruk-konstruk bersama-sama dan juga untuk menilai kekuatan pengujian dari model penelitian. Teknik Partial Least Squares (PLS) digunakan karena alat ini banyak dipakai untuk analisis kausal-prediktif (causal-predictive analysis) yang rumit dan teori yang mendukungnya kurang, PLS merupakan teknik yang cocok digunakan untuk mengembangkan teori. Selanjutnya, pengolahan dan analisis data menggunakan software aplikasi SmartPLS Versi 3.2.8 dengan pengujian diuraikan sebagai berikut:

\subsubsection{Uji Outer Model}

a. Uji Convergent Validity

Pada uji Outer Model ini dilakukan uji indikator reflektif dengan convergent validity, dengan kriteria nilai loading factor 0,50 sampai 0,60 sudah dianggap cukup untuk memenuhi kriteria dan indikator individu dianggap reliable [16,17]. Chin [18] juga menyatakan bahwa nilai loading factor harus diatas 0,70 . Disini penulis mengambil kriteria loading factor $\geq 0,50$ [18].

\section{b. Uji Discriminant Validity}

Pada uji discriminant validity ini untuk melihat nilai korelasi Cross Loading dengan variabel latennya harus lebih besar dibandingkan dengan korelasi terhadap variabel laten yang lain $[16,17]$.

\section{c. AVE (Average Variance Extracted)}

AVE (Average Variance Extracted) ini dilakukan dengan membandingkan nilai square root of average variance extracted atau akar kuadrat dari AVE (average variance extracted) untuk setiap konstruk dengan korelasi antara konstruk dengan konstruk lainnya dalam model. Nilai AVE masing-masing konstruk harus lebih besar dari 0,50 [16,17].

d. Composite Reliability dan Cronbach Alpha

Pada uji validitas, dilakukan juga uji reliabilitas konstruk yang diukur dengan dua kriteria, yaitu composite reliability dan cronbach alpha dari indikator yang mengukur konstruk. Konstruk yang reliabel jika nilai composite reliability maupun cronbach alpha diatas 0,70 $[16,17]$.

\subsubsection{Uji Inner Model}

Pengujian inner model dilakukan dengan melihat nilai R2 yang merupakan uji goodness-fit model, dimana digunakan untuk menguji pengaruh antara satu variabel laten dengan variabel laten lainnya baik eksogen maupun endogen [17]. 
a. R2 untuk Variabel Laten Endogen

Untuk uji R2 variabel laten endogen mengidentifikasikan bahwa hasil R2 sebesar 0,67, 0,33 dan 0,19 untuk variabel laten endogen dalam model struktural mengidentifikasi bahwa model tersebut "baik", "moderat", dan "lemah" [16,17].

b. Koefisien Parameter (Path Coefficient) dan T-Statistik (T-Value)

Pada level signifikansi sebesar 0,05 , suatu hipotesis akan diterima bila memiliki $t$-value lebih besar dari 1,96 [17].

\section{HASIL DAN PEMBAHASAN}

\subsection{Gambaran Umum Responden}

Responden dalam penelitian ini adalah mahasiswa dan dosen yang aktif di lingkungan Sekolah Tinggi XYZ, dimana populasi yang diambil sampel yang dapat mewakili keseluruhan populasi dengan teknik convenience sampling. Kuisioner disebar pada 300 mahasiswa dan dosen, namun yang berhasil dikumpulkan sebanyak 150 kuisioner dan dianggap layak dilakukan analisis.

\subsubsection{Demografi Responden Berdasarkan Jenis Kelamin}

Dari total responden yang berhasil dikumpulkan sebanyak 150 kuisioner tersebut, demografi berdasarkan jenis kelamin diperoleh responden dengan jenis kelamin laki-laki berjumlah 90 orang atau 60\%, dan responden dengan jenis kelamin perempuan berjumlah 60 orang atau $40 \%$.

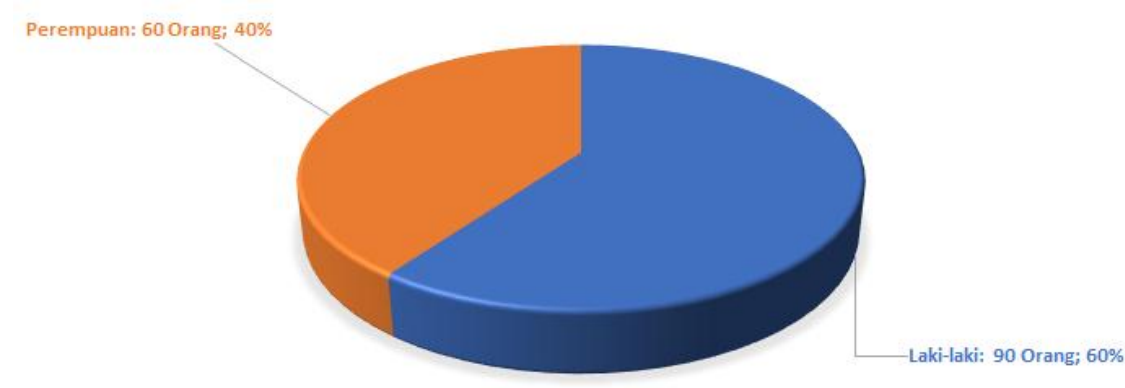

Gambar 2 Demografi Responden Berdasarkan Jenis Kelamin

\subsubsection{Demografi Responden Berdasarkan Usia}

Berdasarkan usia, demografi responden di peroleh antara rentang 17 sampai dengan 30 tahun berjumlah 81 orang laki-laki dan 53 orang perempuan, antara 31 sampai dengan 44 tahun berjumlah 8 orang laki-laki dan 7 orang perempuan, kemudian antara rentang 45 sampai dengan 58 tahun berjumlah 1 orang laki-laki.

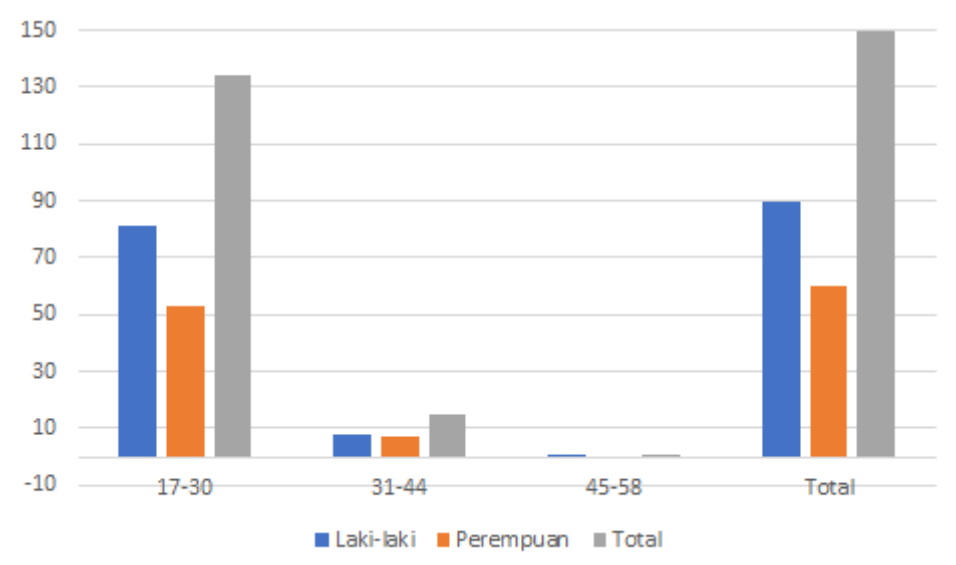

Gambar 3. Demografi Responden Berdasarkan Usia 


\subsubsection{Demografi Responden Berdasarkan mengakses Sistem Informasi dalam 1 (Satu) Minggu}

Demografi responden berdasarkan mengakses Sistem Informasi dalam 1 minggu diperoleh sebagai berikut: untuk responden yang mengakses kurang dari 4 kali berjumlah 48 orang atau 32\%, yang mengakses antara 4 sampai 6 kali berjumlah 63 orang atau $42 \%$ dan yang mengakses lebih dari 6 kali berjumlah 39 orang atau $26 \%$.

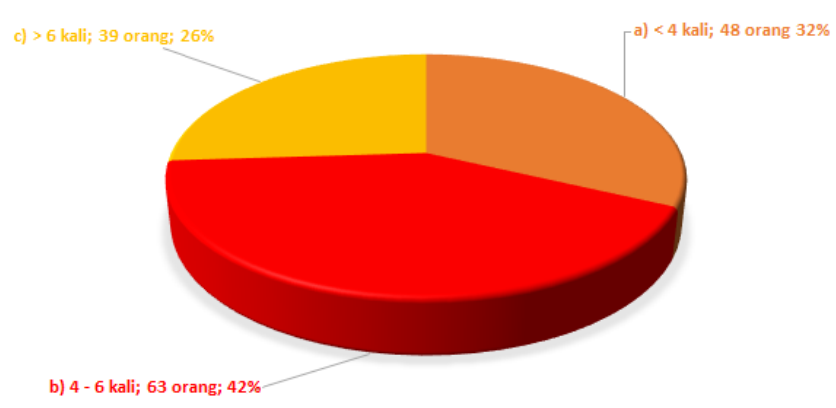

Gambar 4. Demografi Responden Berdasarkan Mengakses Sistem Informasi Dalam 1 (Satu) Minggu

\subsection{Penyusunan Model Berbasis Teori}

Penelitian ini menggunakan model penelitian sebagai berikut:

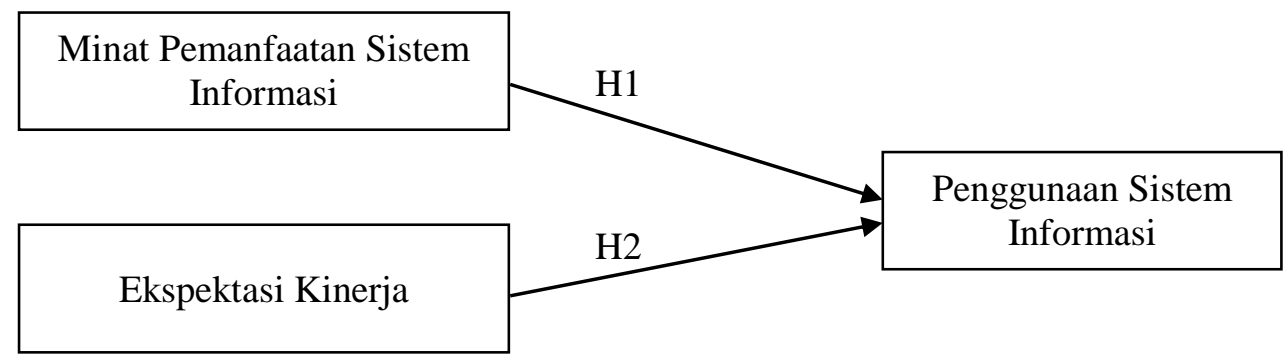

Gambar 5. Model Penelitian

Dari model penelitian ini kemudian digambar dengan menggunakan aplikasi SmartPLS Versi 3.2.8 dan diperoleh gambar sebagai berikut:

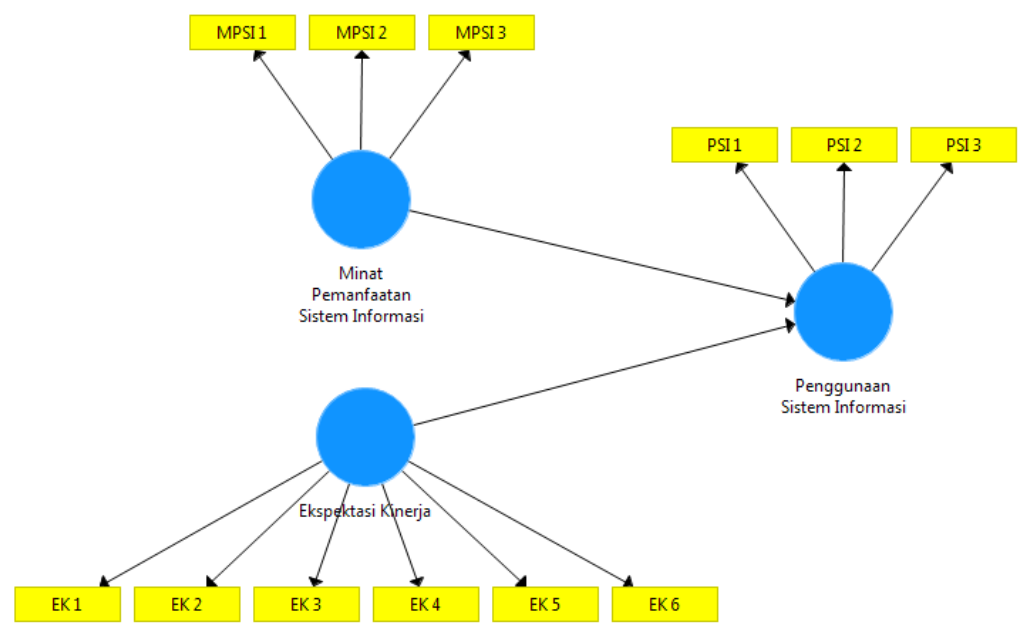

Gambar 6. Model Awal Penelitian

Pada Gambar 6 merupakan model awal penelitian, dimana diagram jalur yang telah dibuat berdasarkan Model Penelitian dengan menggunakan aplikasi SmartPLS Versi 3.2.8. Pada 
aplikasi SmartPLS, variabel laten digambarkan dalam bentuk lingkaran dan indikator digambarkan dalam bentuk kotak segi empat.

\subsection{Uji Model}

Uji Model dilakukan melalui outer model dan inner model. Outer model atau model pengukuran pada prinsipnya menguji indikator terhadap variabel laten, dengan kata lain mengukur seberapa jauh indikator itu dapat menjelaskan variabel latennya dengan cara indikator reflektif diuji dengan convergent validity, discriminant validity atau dengan average variance extracted (AVE) dan composite reliability, kemudian indikator formatif diuji berdasarkan substantive content-nya yaitu membandingkan besarnya relative weight dan melihat signifikansinya. Sedangkan inner model atau model struktural menguji pengaruh antar satu variabel laten dengan variabel laten lainnya baik eksogen maupun endogen. Dapat dikatakan juga menguji hipotesis antara satu variabel laten dengan variabel laten lainnya. Pengujian dilakukan dengan melihat persentase varian yang dijelaskan yaitu R2 untuk variabel laten dependen yang dimodelkan mendapatkan pengaruh dari variabel laten independen menggunakan ukuran stone-geisser $Q$ square test dan melihat besarnya koefisien jalur strukturalnya [7].

\subsubsection{Uji Outer Model}

\section{a. Uji Convergent Validity}

Pada uji Outer Model ini dilakukan uji indikator reflektif dengan convergent validity, dengan kriteria nilai loading factor 0,50 sampai 0,60 sudah dianggap cukup untuk memenuhi kriteria dan indikator individu dianggap reliable [7] [10]. Chin [3] juga menyatakan bahwa nilai loading factor harus diatas 0,70 . Disini penulis mengambil kriteria loading factor $\geq 0,50$. Pada uji convergent validity dapat dilihat pada Gambar 7.

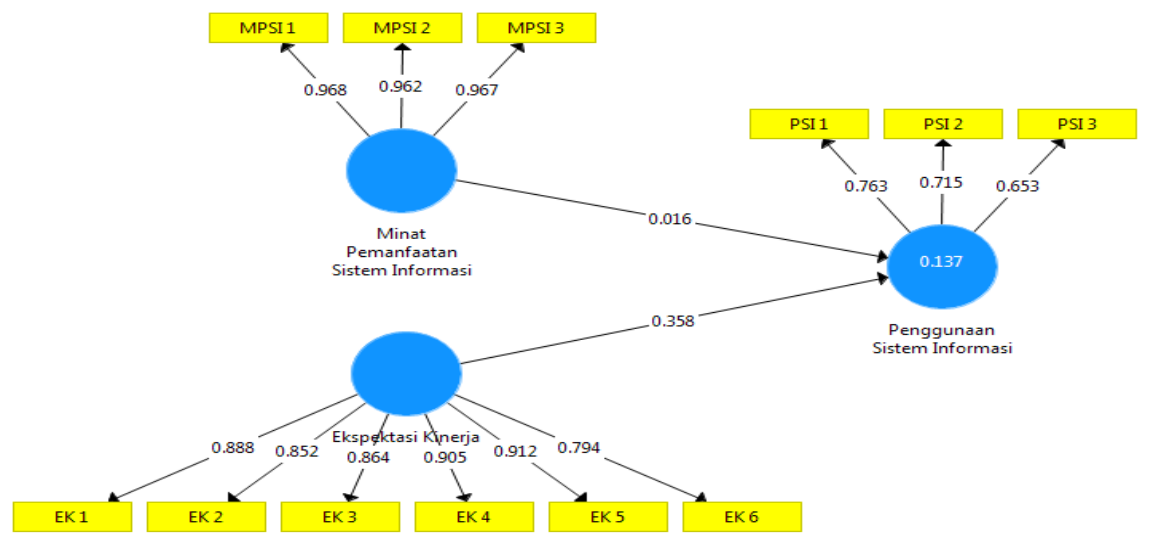

Gambar 7. Uji Convergent Validity

Pada Gambar 7 uji convergent validity memperlihatkan bahwa uji dilakukan dengan menggunakan model awal penelitian. Hasil dari uji convergent validity dapat dilihat pada Tabel 1 .

Tabel 1. Hasil Uji Convergent Validity (Outer Loadings)

\begin{tabular}{|l|c|c|c|}
\hline & $\begin{array}{c}\text { Ekspektasi } \\
\text { Kinerja }\end{array}$ & $\begin{array}{c}\text { Minat Pemanfaatan } \\
\text { Sistem Informasi }\end{array}$ & $\begin{array}{c}\text { Penggunaan } \\
\text { Sistem Informasi }\end{array}$ \\
\hline EK 1 & 0,888 & & \\
\hline EK 2 & 0,852 & & \\
\hline EK 3 & 0,864 & & \\
\hline EK 4 & 0,905 & & \\
\hline EK 5 & 0,912 & & \\
\hline EK 6 & 0,794 & & \\
\hline MPSI 1 & & 0,968 & \\
\hline MPSI 2 & & 0,962 & \\
\hline
\end{tabular}




\begin{tabular}{|l|l|l|l|} 
MPSI 3 & & 0,967 & \\
\hline PSI 1 & & & 0,763 \\
\hline PSI 2 & & & 0,715 \\
\hline PSI 3 & & & 0,653 \\
\hline
\end{tabular}

Pada Tabel 1 dapat dilihat hasil uji convergent validity dari model awal penelitian. Dari Tabel 1 tersebut telihat bahwa indikator-indikator yang terdapat pada model awal penelitian tidak ada yang memiliki nilai loading factor dibawah 0,5 atau indikator yang tidak signifikan sehingga hasil tersebut telah memenuhi uji convergent validity.

\section{b. Uji Discriminant Validity}

Pada uji discriminant validity ini untuk melihat nilai korelasi Cross Loading dengan variabel latennya harus lebih besar dibandingkan dengan korelasi terhadap variabel laten yang lain [7] [10].

Tabel 2. Hasil Uji Discriminant Validity (Latent Variable Correlations)

\begin{tabular}{|l|c|c|c|}
\hline & $\begin{array}{c}\text { Ekspektasi } \\
\text { Kinerja }\end{array}$ & $\begin{array}{c}\text { Minat Pemanfaatan } \\
\text { Sistem Informasi }\end{array}$ & $\begin{array}{c}\text { Penggunaan } \\
\text { Sistem Informasi }\end{array}$ \\
\hline Ekspektasi Kinerja & 1,000 & 0,764 & 0,370 \\
\hline $\begin{array}{l}\text { Minat Pemanfaatan } \\
\text { Sistem Informasi }\end{array}$ & 0,764 & 1,000 & 0,289 \\
\hline $\begin{array}{l}\text { Penggunaan Sistem } \\
\text { Informasi }\end{array}$ & 0,370 & 0,289 & 1,000 \\
\hline
\end{tabular}

Terlihat pada Tabel 2 bahwa nilai korelasi indikator terhadap konstruknya sendiri lebih besar dibandingkan dengan korelasi antara indikator dengan konstruk lainnya, sehingga dapat disimpulkan bahwa konstruk dalam penelitian ini memiliki discriminant validity yang tinggi.

c. AVE (Average Variance Extracted)

AVE (Average Variance Extracted) ini dilakukan dengan membandingkan nilai square root of average variance extracted atau akar kuadrat dari AVE (average variance extracted) $(\sqrt{A V E})$ untuk setiap konstruk dengan korelasi antara konstruk dengan konstruk lainnya dalam model. Jika nilai akar kuadrat AVE setiap konstruk lebih besar daripada nilai korelasi antara konstruk dengan konstruk lainnya dalam model, maka dapat dikatakan memiliki nilai discriminant validity yang baik. Nilai AVE masing-masing konstruk harus lebih besar dari 0,50. [7][10]. Hasil nilai AVE dan akar kuadrat dari AVE dapat dilihat pada Tabel 3.

Tabel 3. Nilai AVE dan Hasil Akar Kuadrat AVE

\begin{tabular}{|l|c|c|}
\hline & $\begin{array}{c}\text { Average Variance } \\
\text { Extracted (AVE) }\end{array}$ & $\sqrt{ }$ AVE \\
\hline Ekspektasi Kinerja & 0,757 & 0,870 \\
\hline Minat Pemanfaatan Sistem Informasi & 0,933 & 0,966 \\
\hline Penggunaan Sistem Informasi & 0,506 & 0,711 \\
\hline
\end{tabular}

Dari Tabel 3 dapat dilihat bahwa Ekspektasi Kinerja (EK) memiliki nilai AVE $=0,757$ dan nilai $=0,870$, Minat Pemanfaatan Sistem Informasi (MPSI) memiliki nilai AVE $=0,933$ dan nilai $=0,966$ dan Penggunaan Sistem Informasi memiliki nilai AVE $=0,506$ dan nilai $=0,711$.

Dapat dilihat secara keseluruhan nilai AVE masing-masing konstruk dalam model yang diestimasi memiliki nilai $\geq 0,50$, sehingga disimpulkan semua konstruk dalam model memenuhi kriteria discriminant validity.

Perbandingan nilai akar kuadrat AVE dengan korelasi variabel laten dapat dilihat pada Tabel 4 
Tabel 4. Perbandingan Nilai Akar Kuadrat AVE dengan Korelasi Variabel Laten

\begin{tabular}{|l|c|c|c|}
\hline & $\begin{array}{c}\text { Ekspektasi } \\
\text { Kinerja }\end{array}$ & $\begin{array}{c}\text { Minat Pemanfaatan } \\
\text { Sistem Informasi }\end{array}$ & $\begin{array}{c}\text { Penggunaan Sistem } \\
\text { Informasi }\end{array}$ \\
\hline Ekspektasi Kinerja & 0,870 & & \\
\hline Minat Pemanfaatan Sistem Informasi & 0,764 & 0,966 & \\
\hline Penggunaan Sistem Informasi & 0,370 & 0,289 & 0,712 \\
\hline
\end{tabular}

Pada Tabel 4dapat dilihat bahwa nilai akar kuadrat AVE lebih besar dibandingkan dengan korelasi antara konstruk lainnya.

d. Composite Reliability dan Cronbach Alpha

Pada uji validitas, dilakukan juga uji reliabilitas konstruk yang diukur dengan dua kriteria, yaitu composite reliability dan cronbach alpha dari indikator yang mengukur konstruk. Konstruk yang reliabel jika nilai composite reliability maupun cronbach alpha diatas 0,70 [7] [10].

Tabel 5. Composite Reliability dan Cronbach Alpha

\begin{tabular}{|l|c|c|}
\hline & Composite Reliability & Cronbach's Alpha \\
\hline Ekspektasi Kinerja & 0,949 & 0,935 \\
\hline Minat Pemanfaatan Sistem Informasi & 0,976 & 0,964 \\
\hline Penggunaan Sistem Informasi & 0,754 & 0,534 \\
\hline
\end{tabular}

Pada Tabel 5 hasil output composite reliability dan cronbach alpha untuk konstruk Ekspektasi Kinerja dan Minat Pemanfaatan Sistem Informasi diatas 0,70 sehingga dapat disimpulkan bahwa konstruk memiliki reliabilitas yang baik. Sedangkan konstruk Penggunaan Sistem Informasi hasil output composite reliability 0.754 memiliki reliabititas yang baik namun cronbach alpha memiliki reliabilitas 0.534 rendah.

\subsubsection{Uji Inner Model}

Pengujian inner model dilakukan dengan melihat nilai $\mathrm{R}^{2}$ yang merupakan uji goodnessfit model, dimana digunakan untuk menguji pengaruh antara satu variabel laten dengan variabel laten lainnya baik eksogen maupun endogen [7]. Dapat dikatakan juga menguji hipotesis antara satu variabel laten dengan variabel laten lainnya. Stabilitas dari estimasi di uji dengan menggunakan uji t-statistik yang diperoleh lewat prosedur bootstrapping [10].

a. $\mathrm{R}^{2}$ untuk Variabel Laten Endogen

Untuk uji $\mathrm{R}^{2}$ variabel laten endogen mengidentifikasikan bahwa hasil $\mathrm{R}^{2}$ sebesar 0,67 , 0,33 dan 0,19 untuk variabel laten endogen dalam model struktural mengidentifikasi bahwa model tersebut "baik", "moderat", dan "lemah".[7] [10]. Hasil uji $\mathrm{R}^{2}$ Variabel laten endogen disajikan pada Tabel 6.

Tabel 6. Uji $\mathbf{R}^{2}$ Variabel Laten Endogen

\begin{tabular}{|l|c|c|c|}
\hline & R Square & Presentase & keterangan \\
\hline Penggunaan Sistem Informasi & 0.137 & $13.7 \%$ & Lemah \\
\hline
\end{tabular}

b. Koefisien Parameter (Path Coefficient) dan T-Statistik (T-Value)

Pengujian hipotesis selanjutnya dilakukan dengan melihat nilai $t$-value pada setiap path coefficient. Untuk mengetahui nilai signifikansi dari path coefficient, maka dilakukan dengan teknik resampling bootstrapping. Pada level signifikansi sebesar 0,05 , suatu hipotesis akan diterima bila memiliki $t$-value lebih besar dari 1,96 [7].

Koefisien Parameter (Pathh Coefficient) dan T-Statistik (T-Value) yang diuji pada Ekspektasi Kinerja (EK) terhadap Penggunaan Sistem Informasi (PSI) dan Minat Pemanfaatan Sistem Informasi (MPSI) terhadap Penggunaan Sistem Informasi (PSI) diuraikan pada Tabel 7. 
Tabel 7. Koefisien Parameter (Path Coefficient) dan T-Statistik (T-Value)

\begin{tabular}{|l|c|c|c|c|}
\hline & $\begin{array}{c}\text { Original } \\
\text { Sample (O) }\end{array}$ & T Statistik (|O/STDEV $\mid)$ & Keterangan & Kesimpulan \\
\hline EK -> PSI & $\mathbf{0 . 3 5 8}$ & 3.319 & Signifikan & H2 : Hipotesis Diterima \\
\hline MPSI -> PSI & 0.016 & 0.130 & Tidak Signifikan & H1 : Hipotesis Ditolak \\
\hline
\end{tabular}

Dari Tabel 7 disimpulkan hasil uji hipotesis terhadap model penelitian dengan pembahasan sesuai dengan urutan hipotesis yang diajukan sebagai berikut:

1. Hipotesis $\mathrm{H} 1$ pada penelitian ini adalah MPSI tidak berpengaruh secara positif ke PSI, hal ini ditunjukan dari hasil Original Sample (O) sebesar 0,016. Dengan demikian Hipotesis H1 ditolak.

2. Hipotesis $\mathrm{H} 2$ pada penelitian ini adalah EK berpengaruh positif terhadap PSI, hal ini ditunjukan dari hasil Original Sample (O) sebesar 0,358. Dengan demikian Hipotesis H2 diterima.

\section{KESIMPULAN DAN SARAN}

\subsection{Kesimpulan}

Dari uji model yang dilakukan diketahui bahwa minat penggunaan sistem informasi tidak memiliki pengaruh yang signifikan atau tidak berpengaruh secara positif terhadap penggunaan sistem informasi, sedangkan variabel espektasi kinerja berpengaruh secara signifikan atau berpengaruh positif terhadap penggunaan sistem informasi. Hal ini dapat disimpulkan bahwa responden yang ada pada Sekolah Tinggi XYZ meyakini bahwa dengan menggunakan sistem akan membantu dalam meningkatkan kinerjanya hal ini adanya hubungan positif yang kuat antara kesesuaian tugas dengan penggunaan sistem.

\subsection{Saran}

Dari analisis penelitian terdapat beberapa saran yaitu:

1. Penelitian dapat dikembangkan lagi dengan mengembangkan model kesusksesan informasi yang lain seperti Model DeLone dan McLean dengan mengukur tingkat kesuksesan informasi.

2. Peneliti diharapkan dapat mengawasi pengisian kusioner dalam pengambilan jawaban dari responden, sehingga hasil yang diperoleh sesuai dengan kondisi yang sebenar-benarnya terjadi.

3. Penelitian berikutnya diharpkan dapat menambah variabel independen dan menambah jumlah sampel untuk membuktikan kembali variabel dalam penelitian ini.

4. Analisa data dapat dilakukan dengan menggunakan alat uji statistik lain misalnya SPSS, AMOS dan Lisrel.

\section{DAFTAR PUSTAKA}

[1] Bodnar, G.H dan William S., Hopwood, 1995, Accounting Information System, Ed 6, Prentice Hall International.

[2] Hall, James A, 2001, Sistem Informasi Akuntansi, Edisi Ketiga, Salemba Empat, Jakarta.

[3] Lucas, H.C.Jr., 1982, Information System Concept for Management, International Student Edition, Tokyo: McGraw-Hill Kogakusha, Ltd. 
[4] Afrizon, 2002, Pengaruh Kebermanfaatan, Kemudahaan Pemakaian, Keterjelasan Hasil, dan Norma Subyektif Dengan Ketakwajiban Sebagai Pemoderasi Terhadap Intensitas Penggunaan Sistem Informasi, Tesis, Program Pasca Sarjana UGM.

[5] Triandis, H.C, 1980, Values, Attitudes and Interpersonal Behaviour, 1979, Believes, Attitude and Values, Nebraska Symposium on Motivation, University of Nebraska Press, Lincoln, NE.

[6] F.D. 1989, Perceived Usefulness, Perceived Ease of Use, and User Acceptance of Information Technology, MIS Quarterly, Vol.13, No.5, 319-339.

[7] Thompson, RL, Higgins, CA and Howell, JM, 1991, Personal Computing: Toward A Conceptual Model of Utilization, MIS Quartely, March.

[8] Venkatesh, V., and Davis, F.D., 2000, A Theoritical Extension of the Technology Acceptance Model: Four Longitudinal Field Studies, Management Science, Vol.46, No.2, 186-204.

[9] Handayani, Rini, 2007, Analisis Faktor-faktor yang Mempengaruhi Minat Pemanfaatan Sistem Informasi dan Penggunaan Sistem Informasi (Studi Empiris pada Perusahaan Manufaktur di Bursa Efek Jakarta), Simposium Nasional Akuntansi X, Unhas Makassar, 26-28 Juli 2007.

[10] Diana, P.M., 2001, Studi Empiris Tentang Faktor-faktor yang Mempengaruhi Pemanfaatan Personal Computing dan Dampaknya Terhadap Kinerja Karyawan Akuntansi, Tesis, Universitas Gajah Mada, Yogyakarta

[11] Compeau, D.R and Higgins, C.A. 1995, Application of Social Cognitive Theory to Training for Computer Skill, Information Systems Research, Vol.6, No.2, 118-143.

[12] Sugiyono, 2016, Metode Penelitian Kuantitatif Kualitataif dan Kombinasi (Mixed Methods), Alfabeta, Bandung.

[13] Sugiyono, 2014, Metode Penelitian Pendidikan Pendekatan Kuantitatif, Kualitatif, dan $R \& D$, Alfabeta, Bandung

[14] Sugiyono, 2013, Metodelogi Penelitian Kuantitatif, Kualitatif Dan R\&D., Alfabeta, Bandung.

[15] Moore, G.C and Benbasat, I., 1991, Development of an Instrument to Measure the Perseption of Adopting an Information Technology Innovation, Information System Research, Vol.2, No.3, 192-222.

[16] Gendro Wiyono, 2011, Merancang Penelitian Bisnis dengan Alat Analisis SPSS 17.0 \& SmartPLS 2.0, UPP STIM YKPN, Yogyakarta.

[17] Imam Ghozali, 2011, Structural Equation Modeling Metode Alternatif dengan Partial Least Square (PLS), Badan Penerbit Universitas Diponegoro, Semarang.

[18] Chin, W. W., 1998, The Partial Least Squares Aproach to Structural Equation Modeling, Modern Methods for Business Research, 295, 336. 